\title{
RANCANG BANGUN MODEL SISTEM INFORMASI PELAYANAN TERPADU SATU PINTU UNTUK MENINGKATKAN KUALITAS PELAYANAN SEKOLAH
}

\author{
Al Husain*1, Ayu Nur Athiyyah Effendi ${ }^{2}$, Meisah Nurma Novita ${ }^{3}$ \\ ${ }^{1}$ Program Studi Teknik Informatika Universitas Raharja, ${ }^{2,3}$ Program Studi Sistem Informasi \\ Universitas Raharja \\ Email : *11alhusain@ raharja.info, ${ }^{2}$ ayu @ raharja.info, ${ }^{3}$ meisah@ raharja.info
}

\begin{abstract}
Abstraksi
Proses pelayanan dibeberapa sekolah pada saat ini masih berjalan kurang efektif, dikarenakan adanya proses yang masih manua, seperti penggunaan buku besar untuk pengarsipan dan pencatatan data yang dikelola, hal ini membutuhkan waktu yang lama dan biaya yang besar, sehingga dirasa tidak efektif dan efisien. Untuk mengatasi permasalahan ini, dibutuhkan sistem yang terkomputerisasi sehingga bisa mengatasi permasalahan dan mampu membantu dalam mempercepat proses, selain itu dapat meningkatkan kualitas pelayanan. Penelitian ini mengusulkan rancangan sistem informasi pelayanan terpadu satu pintu secara otomatis menggunakan berbagai metode yang meliputi metode pengumpulan data melalui proses obeservasi dan wawancara, metode analisa yang saat ini maupun yang diharapkan menggunakan pieces untuk mengevaluasi kinerja dan metode rancangan menggunakan uml (unified modeling language) yang meliputi usecase diagram, squence diagram dan activity diagram sebagai alat untuk menggambarkan bahasa pemrograman berorientasi objek dan penggunaan mysql untuk pengelolaan database, yang pada akhirnya akan menghasilkan suatu sistem yang terintegrasi dengan baik. Sehingga penelitian ini mampu menigkatkan kualitas pelayanan sekolah.
\end{abstract}

Kata Kunci: Pelayanan terpadu, pelayanan satu pintu, kualitas pelayanan sekolah.

\begin{abstract}
The service process in some schools is still running ineffectively, due to the aging process, such as the use of ledgers for archiving and recording of data that is managed, this requires a long time and a large cost, so it is deemed ineffective and inefficient. To overcome this problem, a computerized system is needed so that it can overcome the problem and be able to assist in speeding up the process, besides that it can improve the quality of service. This study proposes the design of a one-stop integrated service information system automatically using various methods including methods of data collection through the process of observation and interviews, current and expected analysis methods using pieces to evaluate performance and design methods using uml (unified modeling language) which includes usecase diagrams, squares diagrams and activity diagrams as tools to describe object-oriented programming languages and the use of mysql for database management, which in turn will produce a wellintegrated system. So this research can improve the quality of school services.
\end{abstract}

Keywords: Integrated services, one door service, quality of school service.

\section{PENDAHULUAN}

Saat ini sekolah berlomba-lomba untuk menciptakan sebuah teknologi yang mampu menopang dan dapat meningkatkan mutu pelayanan menjadi lebih baik, cepat dan efisien. 
Untuk mewujudkan peningkatan mutu pelayanan yang lebih baik, cepat dan efisien ada dua yang menjadi faktor utama yaitu sumber daya manusia dan penerapan sistem informasi yang tepat sasaran. Sistem informasi saat ini menjadi suatu kebutuhan yang penting sekali penerapannya didalam sebuah intansi pendidikan guna kelancaran dalam pertukaran informasi, dengan pertukaran informasi yang cepat bukan mustahil bagi instansi pendidikan dapat memberikan pelayanan yang maksimal.

Proses penanganan pelayanan terpadu satu pintu dibeberapa sekolah saat ini masih manual. Berawal dari proses penerimaan tamu, verifikasi kelengkapan data diri yang diajukan oleh staff PTSP, masih perlu disesuaikan dengan prosedur pencatatan yang masih menggunakan buku tamu. Proses selanjutnya, pada tahapan penerimaan surat masuk dan pendataannya juga masih mencatat menggunakan buku catatan surat masuk. Ada juga tahapan pendistribusian surat keluar juga masih dilakukan secara manual dengan mencatat nama yang bersangkutan dibuku ekspedisi, Kemudian staff mencari guru/staff/kepegawaian yang bersangkutan, sehingga staff harus meninggalkan tempat, jika ditempat tidak ada staff maka akan menghambat proses kinerja. Selanjutnya proses legalisir masih menggunakan buku legalisir. Berikutnya proses laporan kepada kepala sekolah yang dilakukan oleh staff dalam periode mingguan maupun bulanan masih dilakukan dengan manual,sehingga, sering terjadi kesalahan data yang diperoleh dalam penghitungan data tamu, data legalisir, data surat masuk, dan data surat keluar.

Pelayanan adalah pemberian jasa baik oleh pemerintah, pihak swasta atas nama pemerintah ataupun pihak swasta kepada masyarakat, dengan tanpa pembayaran guna memenuhi kebutuhan dan kepentingan masyarakat [1][2]. pelayanan adalah kegiatan yang dilakukan oleh seseorang atau sekelompok orang dengan landasan faktor materi melalui sistem, prosedur dan metode tertentu dalam rangka usaha memenuhi kepentingan orang lain sesuai dengan haknya[3][4].

Pelayanan terpadu satu pintu adalah salah satu program pemerintah dalam upaya meningkatkan pelayanan publik, memangkas birokrasi pelayanan izin serta sebagai upaya mencapai good governance atau pemerintahan yang baik, yang sudah dicanangkan sejak tahun 2006[5][6]. Pelayanan terpadu satu pintu adalah aktivitas atau kegiatan penyelenggaraan perizinan berdasarkan pelimpahan wewenang dari lembaga atau instansi yang mempunyai kewenangan perizinan yang proses pengelolaannya dimulai dari tahap permohonan izin sampai dengan tahap terbitnya dokumen dilakukan dalam satu tempat [7][8].

\section{METODE PENELITIAN}

Metode penelitian merupakan suatu tata cara atau kegiatan pelaksanaan penelitian rangka untuk mengumpulkan informasi atau data serta melakukan investigasi terhadap data yang telah didapatkan tersebut. yang didasari oleh asumsi-asumsi dasar, pandangan-pandangan filosofis dan ideologis, pertanyaan dan isu-isu yang dihadapi [9]. Suatu penelitian mempunyai rancangan penelitian tertentu. Rancangan ini menggambarkan prosedur atau langkah-langkah yang harus ditempuh, waktu penelitian, sumber data dan kondisi arti untuk apa data dikumpulkan dan dengan cara bagaimana data tersebut dihimpun dan diolah untuk dianalisa dalam pembuatan laporan.

\subsection{Metode Observasi (Observasi Research)}

Pada tahapan ini peneliti melakukan pengamatan langsung dari objek penelitian untuk mendapatkan data dan informasi yang akurat dan lengkap dari berbagai pihak yang terkait dan berhubungan dengan tema penelitian yang berhasil peneliti rumuskan di bagian pelayananPeneliti melakukan suatu teknik pengumpulan data dengan jalan wawancara dan tanya jawab sepihak kepada kepala tata ssaha selaku stakeholder yang mempunyai wewenang serta mengetahui tentang seluk beluk dari pelayanan terpadu satu pintu tersebut.Selain melakukan observasi peneliti juga melakukan pencarian data dengan cara studi pustaka dalam metode ini peneliti berusaha untuk melengkapi data-data yang diperoleh dari beberapa sumber (literature) 
seperti browsing internet, jurnal, artikel dan lain sebagainya yang berkaitan dengan penelitian sebagai bahan referensi dalam penyusunan penelitian skripsi ini.

\subsection{Metode Analisis Data}

Pada penelitian ini, metode analisa dilakukan dengan langkah-langkah melakukan pengamatan dan analisa terhadap sistem yangberjalan saat ini, serta menentukan uml yang meliputi use case diagram, activity diagram, sequence diagram.

\section{PEMBAHASAN}

Untuk dapat menggambarkan prosedur secara keseluruhan diperlukan bebrapa tahapan analisa sebagai bentuk pengumpulan informasi guna mendapatkan model yang sesuai dengan kebutuhan dan mampu memberikan solusi dengan cepat secara efektif dan efisien, mulai dari tahapan pengumpulan informasi dan kebutuhan, analisa dokumen, merancangan hubungan antar dokumen sampai dengan merancanga model diagram database dan model rancangan sistem [10]. Beberapa tahapan yang dimaksud sampai dengan model ranangan yang diciptakan dapat dilihat pada gambar 1,2,3,4,5.

\subsection{Use Case Diagram Prosedur Berjalan}

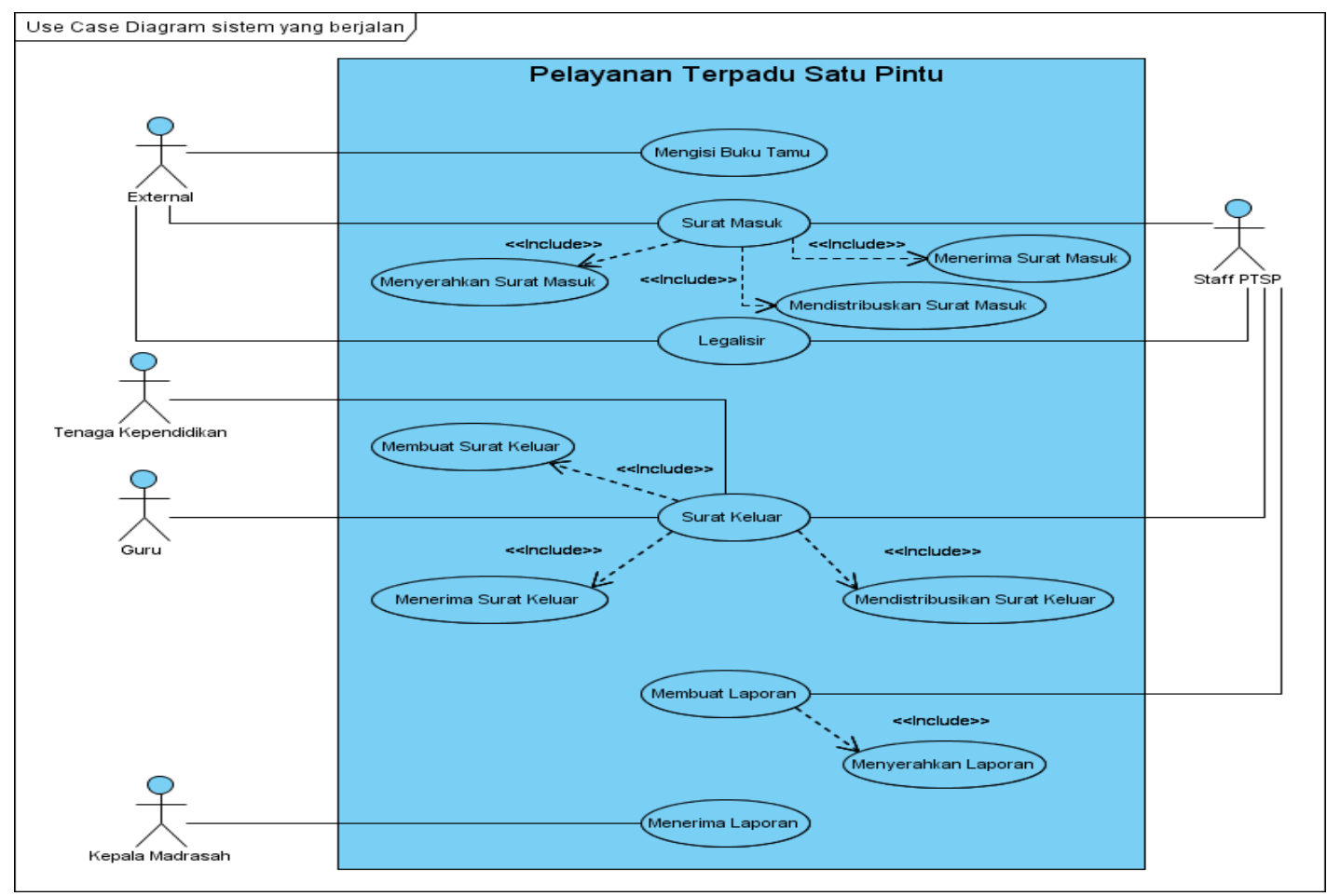

Diagram

Berdasarkan gambar use case diagram (gambar 1) yang berjalan saat ini sistem yang mencakup seluruh kegiatan pada pelayanan terpadu satu pintu. Terdapat 5 (lima) actor yang melakukan kegiatan yaitu external, guru, tenaga kependidikan, staff PTSP, kepala sekolah, yang berfungsi untuk mengisi buku tamu, surat masuk (penyerahan surat masuk, penerimaan surat masuk, mendistribusikan surat masuk), legalisir, surat keluar (membuat surat keluar, mendistribusikan surat keluar, menerima surat keluar), membuat laporan (menyerahkan laporan), menerima laporan.

Terdapat juga 10 (sepuluh) use case yang merupakan external (pengunjung) mengisi buku tamu, external menyerahkan surat masuk, staff ptsp menerima surat masuk, mendistribusikan surat masuk, external ingin legalisir, staff ptsp menerima legalisir, tenaga 
kependidikan membuat surat keluar, staff ptsp mendistribusikan surat keluar, guru menerima surat keluar, staff ptsp membuat laporan lalu menyerahkan laporan dan kepala madrasah menerima laporan.

\subsection{Activity Diagram Prosedur Berjalan}

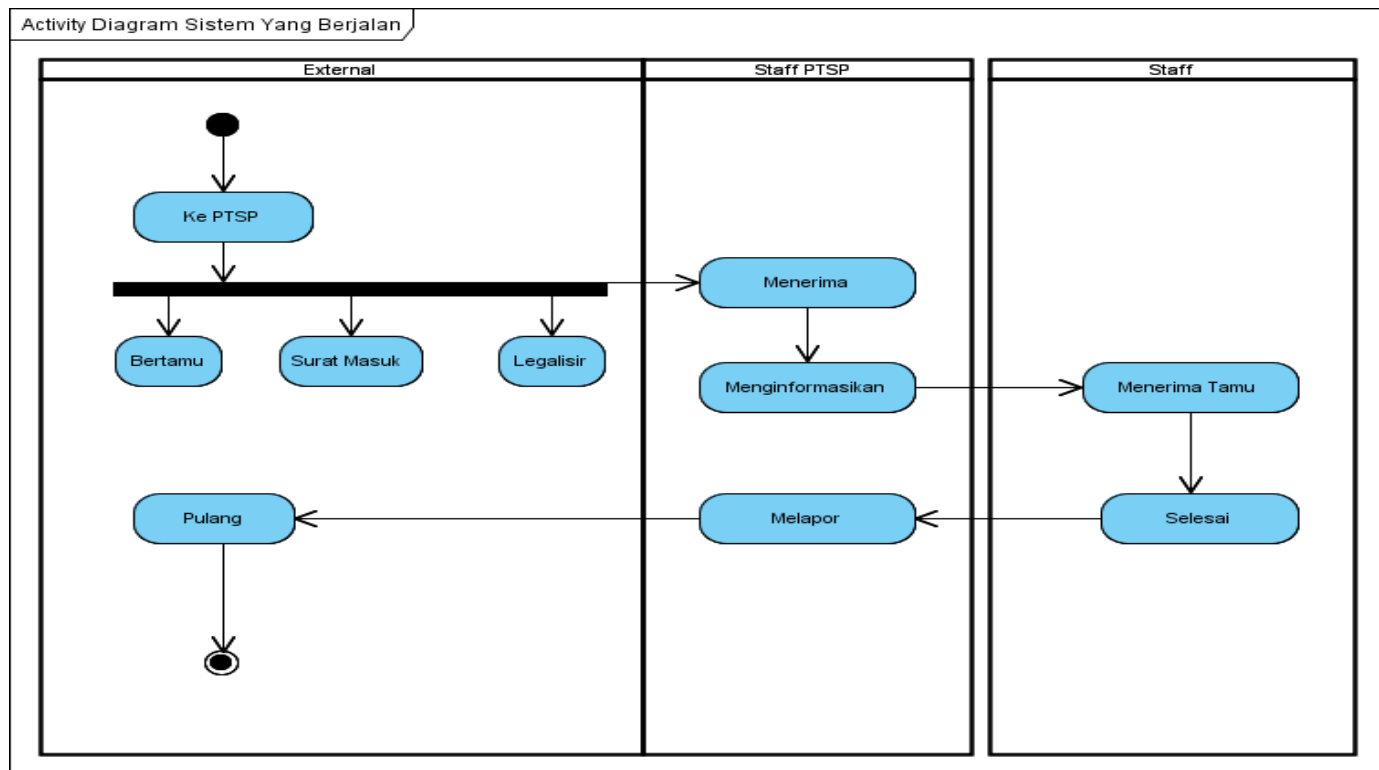

Gambar 2. Activity Diagram

Berdasarkan gambar activity diagram (gambar 2) yang berjalan saat ini sistem mencakup seluruh kegiatan penyediaan suku cadang.Sistem ini melibatkan 3 (tiga) Actor yaitu, external dating keptsp untuk bertamu, mengantar surat masuk, dan melegalisir, staff ptsp menerima tamu, menerima surat masuk, menerima legalisir dan staff ptsp menginformasikan, staff menerima tamu.

\subsection{Squence Diagram Prosedur Berjalan}

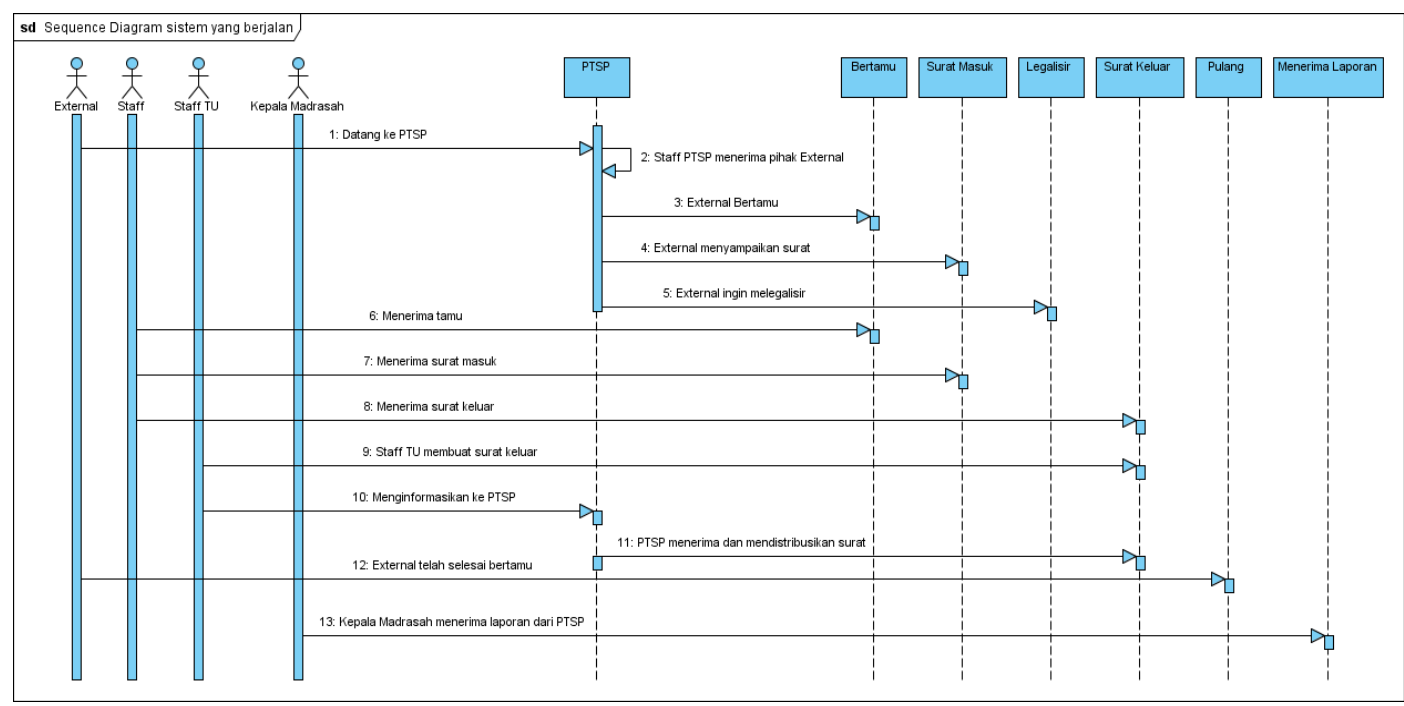

Gambar 3. Squence Diagram 
Berdasarkan gambar sequence diagram (gambar 3) yang berjalan saat ini terlihat 4(tiga) actor yang melakukan kegiatan diantaranya: external, staff, staff Tu, kepala madrasah, yang akan menyelesaikan 13 message spesifikasi dari komunikasi antar objek yang memuatin formasi-informasi tentang aktifitas yang terjadi, yaitu dating keptsp, staff ptsp menerima pihak external, external bertamu, external menyampaikan surat, external ingin melegalisir, menerima tamu, menerima surat masuk, menerima surat keluar, staff tu membuat surat keluar, menginformasikan keptsp, ptsp menerima dan mendistribusikan, external telah selesai bertamu, kepala madrasah menerima laporan dari ptsp.

Rancangan diatas (gambar 1,2,3) merupakan gambaran prosedur yang berjalan dimana pada tahapan ini melibatkan beberapa pengarsipan. Untuk mengisi buku tamu, surat masuk (menyerahkan surat masuk, menerima surat masuk, mendistribusikan surat masuk), legalisir, surat keluar (membuat surat keluar, mendistribusikan surat keluar, menerima surat keluar), membuat laporan (menyerahkan laporan), menerima laporan.

\subsection{Class Diagram}

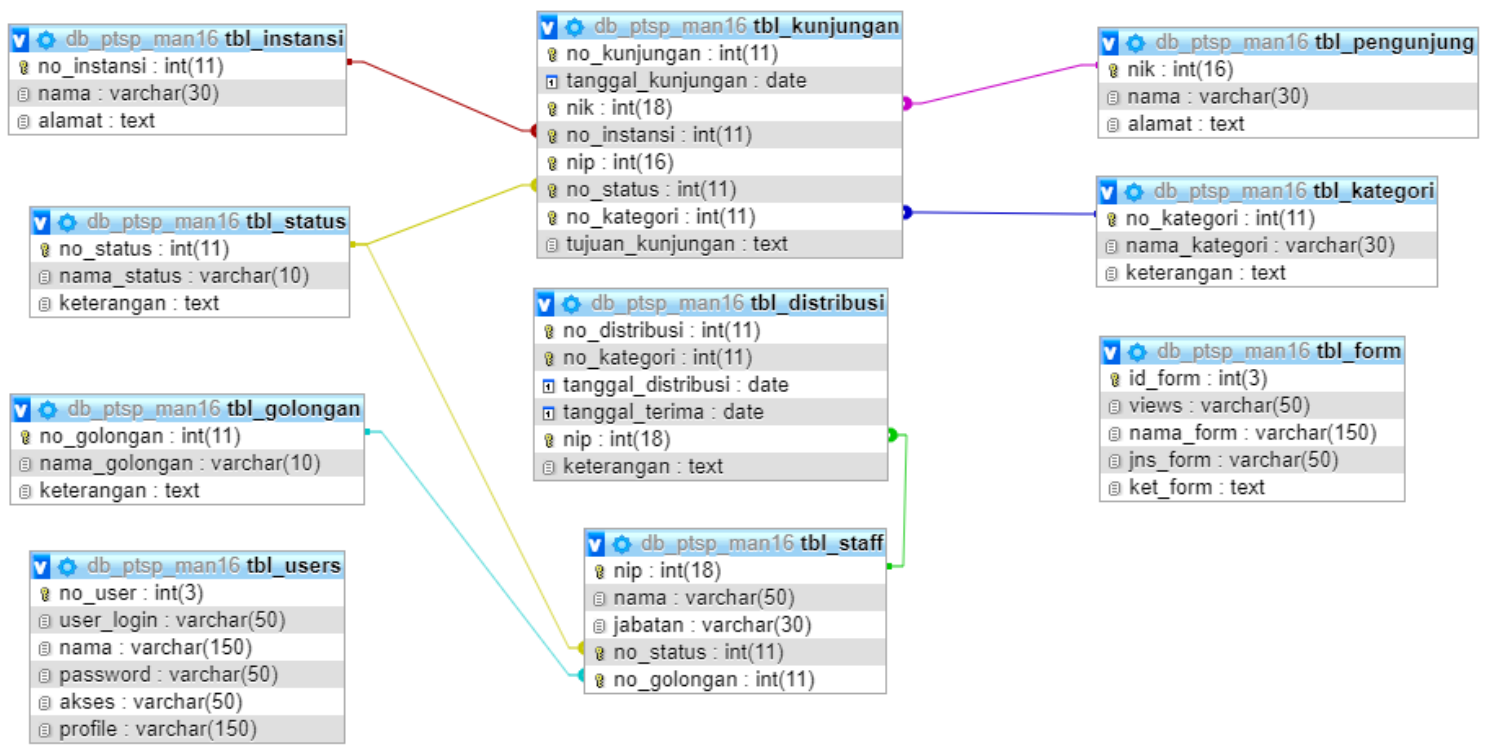

\section{Gambar 4. Class DiagramGambar 1. Use Case DiagramGambar 1. Use Case}

Berdasarkan gambar class diagram (gambar 4) yang berjalan saat ini sistem yang mencakup seluruh kegiatan pada sistem PTSP. Terdapat 10 (sepuluh) class yaitu tbl_status, tbl_golongan, tbl_kategori, tbl_staff, tbl_pengunjung, tbl_instansiyang merupakan tabel master, tbl_kunjungan, tbl_distribusi sebagai tabel transaksi, juga terdapat tabel user yang merupakan table akses untuk masuk kedalam sistem dan table form menyimpan semua pengaturan. Berdasarkan gambar class diagram (gambar 4) diatas dapat dilihat dengan jelas bahwa tingkat hubungan tbl_instansi dan tbl_kunjungan yaitu one to many (1:M), tingkat hubungan tbl_kunjungan dantbl_pengunjung yaitu one to many (1:M), ), tingkat hubungan tbl_kategori dan tbl_kunjungan yaitu one to many (1:M), tingkat hubungan tbl_status dan tbl_kunjungan yaitu one to many (1:M), tingkat hubungan tbl_status dan tbl_staff yaitu one to many (1:M), tingkat hubungan tbl_staff dan tbl_distribusi yaitu one to many (1:M), tingkat hubungan tbl_golongan dan tbl_staff yaitu one to many $(1: \mathrm{M})$.

\subsection{Use Case Diagram Usulan}




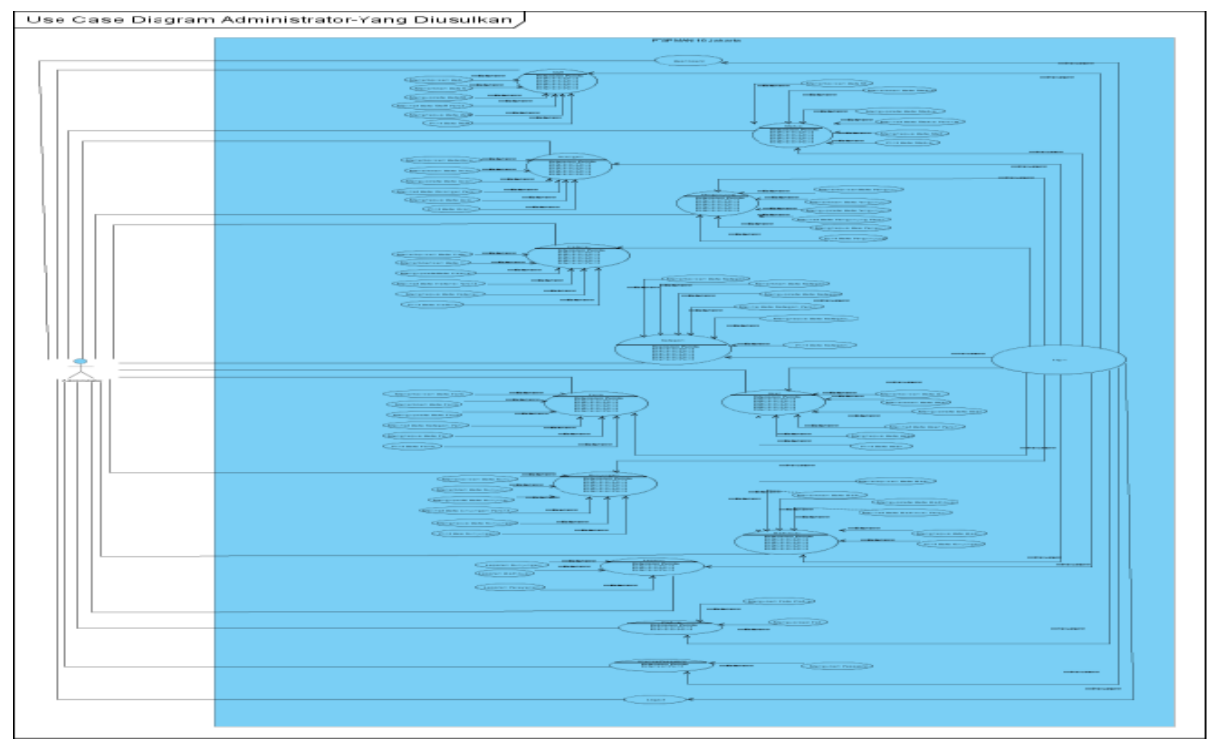

Gambar 5. Use Case Diagram

Berdasarkan gambar use case diagram usulan (gambar 5) terlihat jelas bahwa terdapat 16 (enam belas) yaitu dashboard, staff, status, golongan, pengunjung, instansi, kategori, form, user, kunjungan, distribusi, laporan kunjungan, laporan distribusi, laporan pelayanan profile, change password, login, logout. Dimana login dan logout berfungsi sebagai kontrol untuk memfilter siapa saja yang bisa mengakses sistem, dashboard berfungsi untuk menampilkan rekapitulasi kualitas pelayanan dalam bentuk diagram, staff berfungsi untuk pengelolaan data staff, status berfungsi untuk pengelolaan data status, golongan berfungsi untuk pengelolaan data golongan, pengunjung berfungsi untuk data pengunjung, instansi berfungsi untuk pengelolaan data instansi, kategori berfungsi untuk pengelolaan data kategori, form berfungsi untuk pengelolaan data form, user berfungsi untuk pengelolaan data user, kunjungan berfungsi untuk pengelolaan data kunjungan, distribusi berfungsi untuk pengelolaan data distribusi, laporan kunjungan berfungsi menampilkan laporan kunjungan, laporan distribusi, dan laporan pelayanan, profile berfungsi untuk mengubah foto profile dan mengupload foto profile, change password berfungsi untuk mengubah password.

\subsection{IMPLEMENTASI}

\subsubsection{Rancangan Basis Data}

Untuk dapat menggamarkan bentuk basis data secara utuh, peneliti penggunakan aplikasi microsoft access sebagai bentuk gambaran dasar, dan pada akhirnya bentuk rancangan basis data ini dapat disesuaikan menggunakan apa saja sesuai kebutuhan.

\section{a. Tabel Master : Distribusi}

Primary Key : no_distribusi

Foreign Key : : -

Structure Tabel : \{no_distribusi, no_kategori, tanggal_distribusi, tanggal_terima, nip, keterangan $\}$

\begin{tabular}{|c|c|c|c|c|c|c|c|c|}
\hline & \# & Name & Type & Collation & Attributes & Null & Default Comments & Extra \\
\hline$\square$ & 1 & no_distribusi & $\operatorname{int}(11)$ & & & No & None & AUTO_INCREMENT \\
\hline$\square$ & 2 & no_kategori & $\operatorname{int}(11)$ & & & No & None & \\
\hline$\square$ & 3 & tanggal_distribusi & date & & & Yes & None & \\
\hline$\square$ & 4 & tanggal_terima & date & & & Yes & None & \\
\hline$\square$ & 5 & nip & $\operatorname{int}(18)$ & & & No & None & \\
\hline$\square$ & 6 & keterangan & text & latin1_swedish_ci & & Yes & None & \\
\hline
\end{tabular}

Tabel 1. Struktur Distribusi 


\section{b. Tabel Master: Golongan}

Primary Key : no_golongan

Foreign Key : :

Structure Tabel : \{no_golongan, nama_golongan,keterangan

\begin{tabular}{|c|c|c|c|c|c|c|c|c|}
\hline & $\#$ & Name & Type & Collation & Attributes & Null & Default Comments & Extra \\
\hline$\square$ & 1 & no_golongan & $\operatorname{int}(11)$ & & & No & None & AUTO_INCREMENT \\
\hline$\square$ & 2 & nama_golongan & $\operatorname{varchar}(10)$ & latin1_swedish_ci & & Yes & None & \\
\hline$\square$ & 3 & keterangan & text & latin1_swedish_ci & & Yes & None & \\
\hline
\end{tabular}

c. Tabel Master: Instansi

Tabel 2. Struktur Golongan

Primary Key : no_instansi

Foreign Key : -

Structure Tabel $\quad: \quad\{$ no_instansi, nama, alamat $\}$

\begin{tabular}{|c|c|c|c|c|c|c|c|c|}
\hline & \# & Name & Type & Collation & Attributes & Null & Default Comments & Extra \\
\hline$\square$ & 1 & no_instansi & $\operatorname{int}(11)$ & & & No & None & AUTO_INCREMENT \\
\hline$\square$ & 2 & nama & $\operatorname{varchar}(30)$ & latin1_swedish_ci & & Yes & None & \\
\hline$\square$ & 3 & alamat & text & latin1_swedish_ci & & Yes & None & \\
\hline
\end{tabular}

Tabel 3. Stuktur Instansi

d. Tabel Master: Kategori

Primary Key :no_kategori

Foreign Key : : -

Structure Tabel : $\{$ no_kategori, nama_kategori, keterangan $\}$

\begin{tabular}{|llllll} 
\# & Name & Type & Collation & Attributes & Null Default Comments Extra \\
\hline 1 & no_kategori & int(11) & & No None & AUTO_INCREMENT \\
\hline & 2 & nama_kategori & varchar(30) latin1_swedish_ci & Yes None & \\
\hline 3 & keterangan & text & latin1_swedish_ci & Yes None
\end{tabular}

Tabel 4. Struktur kategori

\section{e. Tabel Master: Kunjungan}

Primary Key :no_kunjungan

Foreign Key : -

Structure Tabel : \{no_kunjungan, tanggal_kunjungan, nik, no_instansi, nip, no_status, no_kategori, tujuan_kunjungan \}

\begin{tabular}{|c|c|c|c|c|c|c|c|c|}
\hline & \# & Name & Type & Collation & Attributes & Null & Default Comments & Extra \\
\hline$\square$ & 1 & no_kunjungan & $\operatorname{int}(11)$ & & & No & None & AUTO_INCREMENT \\
\hline$\square$ & 2 & tanggal_kunjungan & date & & & Yes & None & \\
\hline$\square$ & 3 & nik & $\operatorname{int}(18)$ & & & No & None & \\
\hline$\square$ & 4 & no_instansi & $\operatorname{int}(11)$ & & & No & None & \\
\hline$\square$ & 5 & nip & $\operatorname{int}(16)$ & & & No & None & \\
\hline$\square$ & 6 & no_status & $\operatorname{int}(11)$ & & & No & None & \\
\hline$\square$ & 7 & no_kategori & $\operatorname{int}(11)$ & & & No & None & \\
\hline$\square$ & 8 & tujuan_kunjungan & text & latin1_swedish_ci & & No & None & \\
\hline
\end{tabular}

Tabel 5. Struktur Kunjungan

\section{f. Tabel Transaksi: Pengunjung}

Primary Key : :nik

Foreign Key : : -

Structure Tabel $\quad: \quad\{$ nik, nama, alamat $\}$ 


\begin{tabular}{|c|c|c|c|c|c|c|c|c|c|}
\hline & \# & Name & Type & Collation & Attributes & Null & Default & Comments & Extra \\
\hline$\square$ & 1 & nik & $\operatorname{int}(16)$ & & & No & None & & \\
\hline$\square$ & 2 & nama & $\operatorname{varchar}(30)$ & latin1_swedish_ci & & Yes & None & & \\
\hline$\square$ & 3 & alamat & text & latin1_swedish_ci & & Yes & None & & \\
\hline
\end{tabular}

Tabel 6. Struktur Pengunjung

g. Tabel Transaksi: Staff

Primary Key : nip

Foreign Key : : -

Structure Tabel $\quad: \quad\{$ nip, nama, jabatan, no_status, no_golongan $\}$

\begin{tabular}{|c|c|c|c|c|c|c|c|c|}
\hline & $\#$ & Name & Type & Collation & Attributes & Null & Default Comments & Extra \\
\hline$\square$ & 1 & nip & $\operatorname{int}(18)$ & & & No & None & AUTO_INCREMENT \\
\hline$\square$ & 2 & nama & $\operatorname{varchar}(50)$ & latin1_swedish_ci & & No & None & \\
\hline$\square$ & 3 & jabatan & $\operatorname{varchar}(30)$ & latin1_swedish_ci & & No & None & \\
\hline$\square$ & 4 & no_status & $\operatorname{int}(11)$ & & & No & None & \\
\hline$\square$ & 5 & no_golongan & $\operatorname{int}(11)$ & & & No & None & \\
\hline
\end{tabular}

Tabel 7. Struktur Staff

\subsection{Grafik Monitoring Pergantian Suku Cadang}

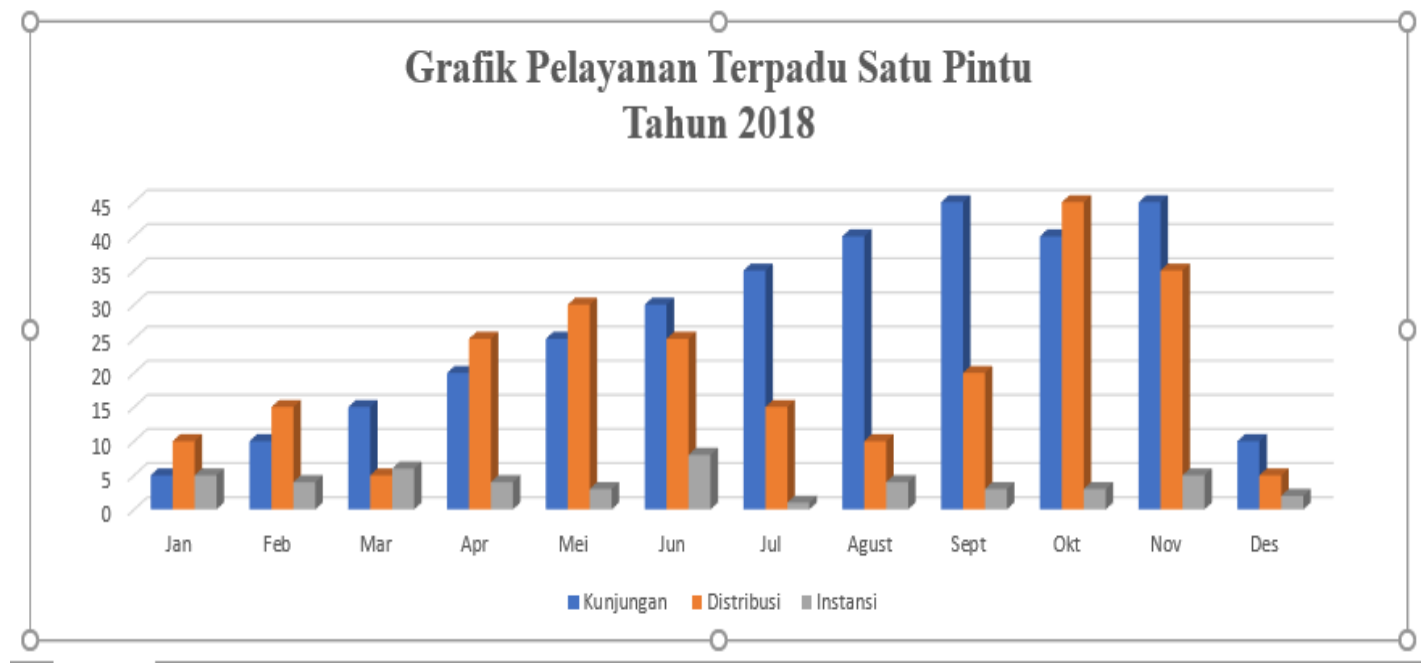

Gambar 6. Grafik PelayananTerpadu Satu Pintu Tahun 2018

Grafik diatas (gambar 6) merupakan grafik monitoring pelayanan terpadu satu pintu berdasarkan waktu (bulan). Hal ini bisa membantu manajemen dalam menunjang keputusan guna pelayanan mana yang menjadi prioritas pelayanan. Grafik diatas bisa diambil berdasarkan Datewarehouse, sebagaimana di definisikan "Doing Data Warehouse (DW) to your business or system is not only think about the trend only, but how to understand the DW knowledge itself and how to implement it" [11]. Dan bagaimana cara mengukurnya "Measures are a standard unit used to express the size, amount, or degree of something, qualities are often difficult to be measured as it needs to have some certain parameter or elements, and those parameters must be quantifiable and verifiable" [12] 


\subsection{Diagram HIPO}

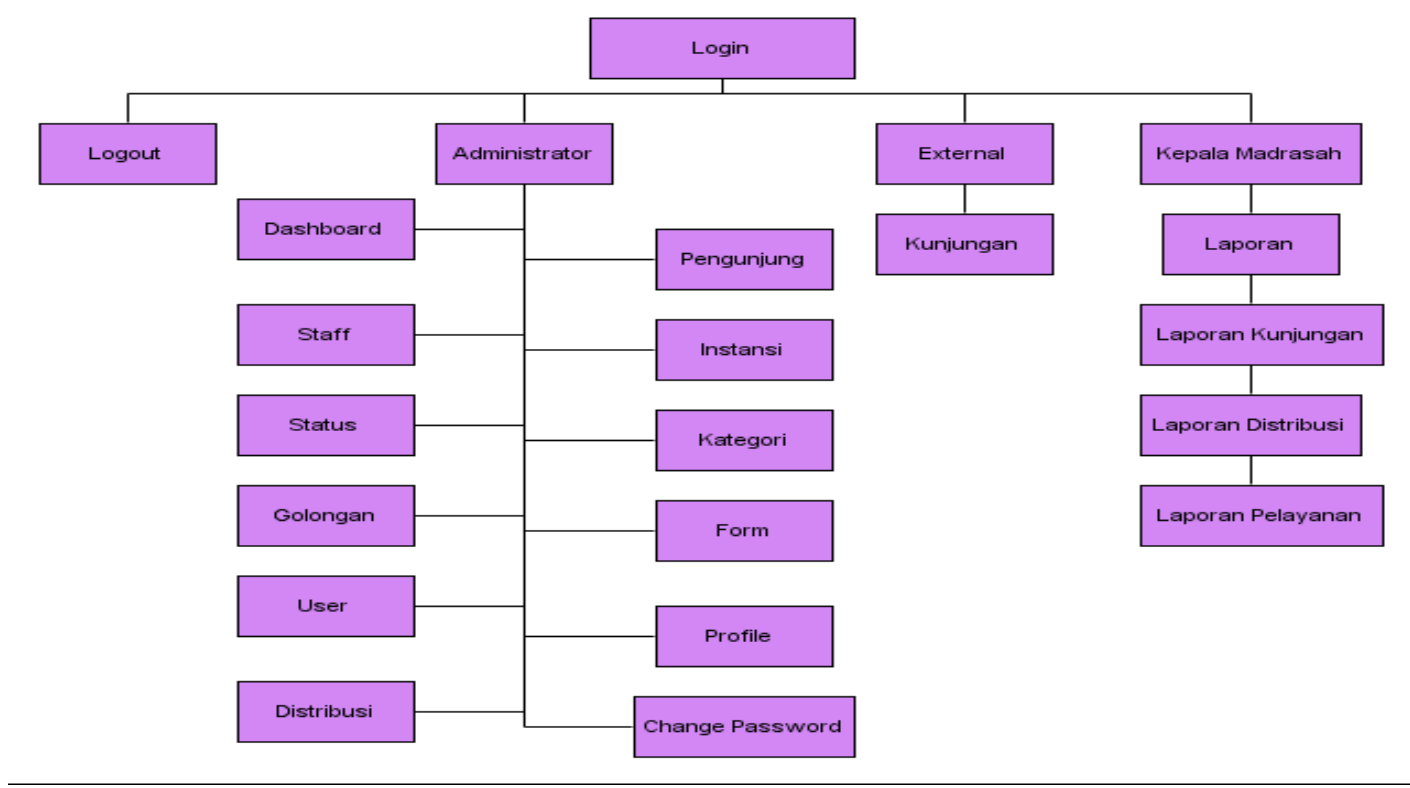

Gambar 7. Diagram HIPO

Untuk menggambarkan stuktur menu dari sistem yang dirancang dapat digambarkan dengan diagram HIPO (Hierarchy Input Process Output). Untuk menyediakan suatu struktur guna memahami fungsi-fungsi dari program. Terlihat dari diagram HIPO diatas (gambar 7) terdapat 1 (satu) fungsi utama yaitu login (diagram 0), menu login ini memiliki 3 hak akses yaitu Administrator (diagram 1), External (diagram 2), Kepala Madrasah (diagram 3), dan menu Logout (diagram 4). Didalam hak akses administrator (diagram 1) terdapat 12 (dua belas) fungsi sub menu yaitu menu Dashboard (diagram 1.1), menu Staff (diagram 1.2), menu Status (diagram 1.3), menu Golongan (diagram 1.4), menu Pengunjung (diagram 1.5), menu Instansi (diagram 1.6), menu Kategori (diagram 1.7), menu Form (diagram 1.8), menu User (diagram 1.9), menu Distribusi (diagram 1.10), menu Profile (diagram 1.11), menu Change Password (diagram 1.12). Didalam hak akses External (diagram 2) terdapat 1 (satu) fungsi sub menu yaitu menu Kunjungan (diagram 2.1). di dalam hak akses Kepala Madrasah (diagram 3), terdapat 1 (satu) fungsi sub menu Laporan (3.1), di dalam fungsi sub menu Laporan terdapat 3 (tiga) sub menu yaitu Laporan Kunjungan (3.1.1), Laporan Distribusi (3.1.2), Laporan Pelayanan (3.1.3).

\subsection{Rancangan Tampilan}

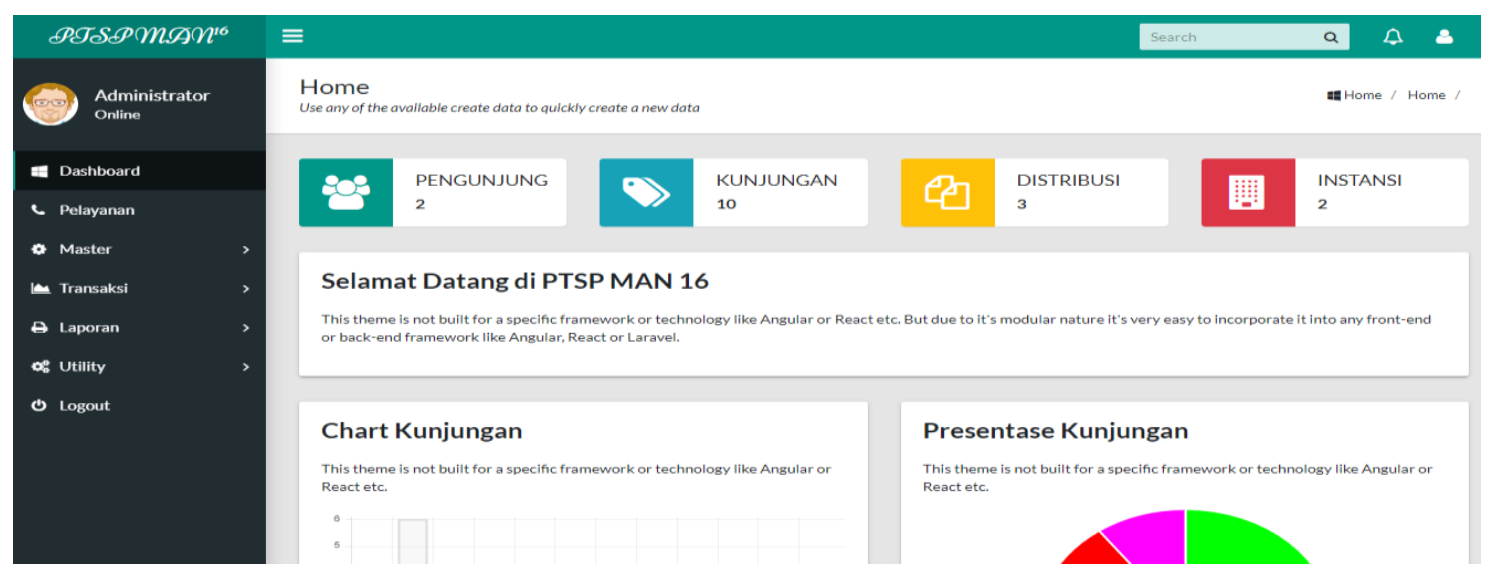

Gambar 8. Tampilan Dashboard 
Terlihat pada tampilan layar diatas (gambar 8) merupakan tampilan layar Dashboard yang terdiri dari menu master, menu transaksi dan menu report.

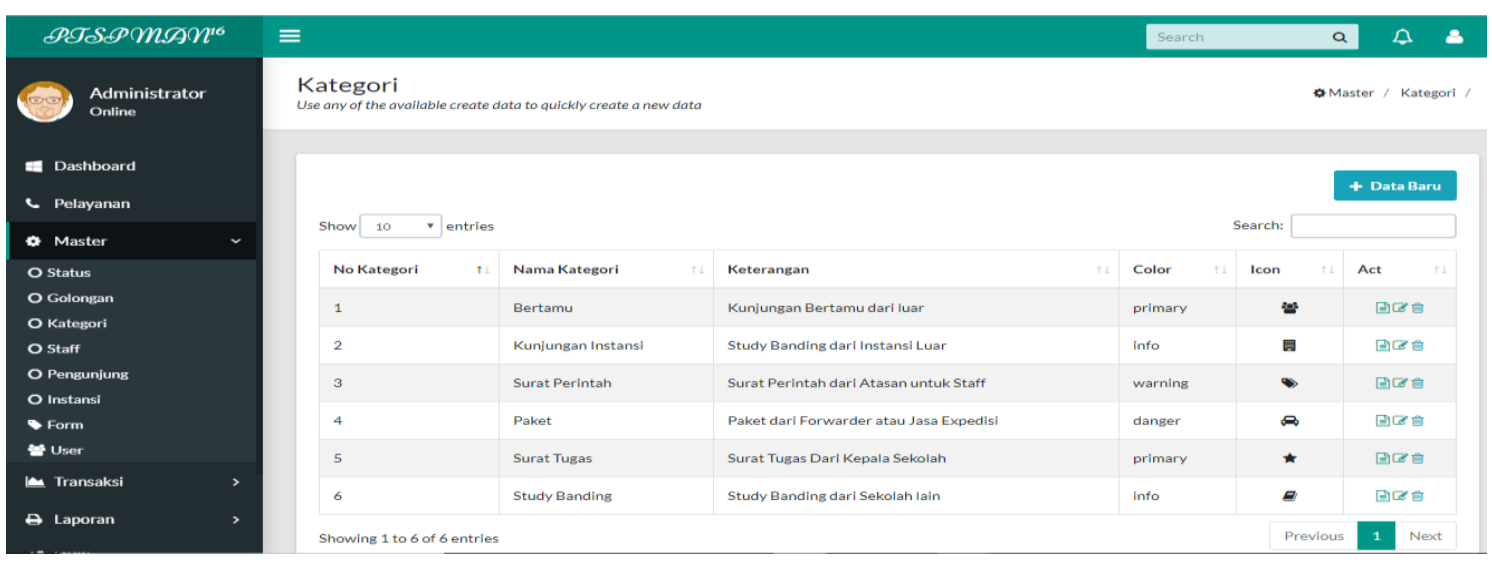

Gambar 9. Tampilan Menu Kategori

Terlihat pada tampilan layar diatas (gambar 9) merupakan tampilan layar Kategori yang terdiri dari menu master, menu transaksi dan menu report, dimana menu transaksi

\subsection{Query Penciptaan Informasi}

\section{Query Function Kategori_list:}

function kategori_list()

\{ $\quad$ \$sql="select * from tbl_kategori";

$\$$ this-> sql $=\$$ sql $; \$ \mathrm{i}=0$;

$\$$ query=\$this->mysqli->query $(\$$ sql) or die (\$this->mysqli->error () );

while (\$result=\$query->fetch_assoc())

\{ \$this->no_kategori[\$i]=\$result['no_kategori'];

\$this->nama_kategori[\$i]=\$result['nama_kategori'];

\$this-> keterangan[\$i]=\$result['keterangan'];

\$this->color[\$i]=\$result['color'];

$\$$ this->icon[ $\$ \mathrm{i}]=\$$ result['icon'];

$\$$ i++; \}

return true; $\$$ this->mysqli->close ()$;\}$

\section{Query Function Kategori_select:}

function kategori_select()

$\{\quad \$$ sql="select $*$ from tbl_kategori

where no_kategori='".\$this->no_kategori."'";

\$this->sql=\$sql;

\$query=\$this->mysqli->query $(\$$ sql) or die (\$this->mysqli->error());

while (\$result=\$query->fetch_assoc())

$\{\quad$ \$this->no_kategori=\$result['no_kategori'];

\$this->nama_kategori=\$result['nama_kategori'];

$\$$ this- $>$ keterangan $=\$$ result['keterangan'];

$\$$ this->color $=\$$ result['color'];

\$this->icon=\$result['icon']; \}

return true; $\quad \$$ this->mysqli->close();

\section{Query Function Kategori_Save:}

function kategori_save()

\{ \$sql="insert into tbl_kategori; set 


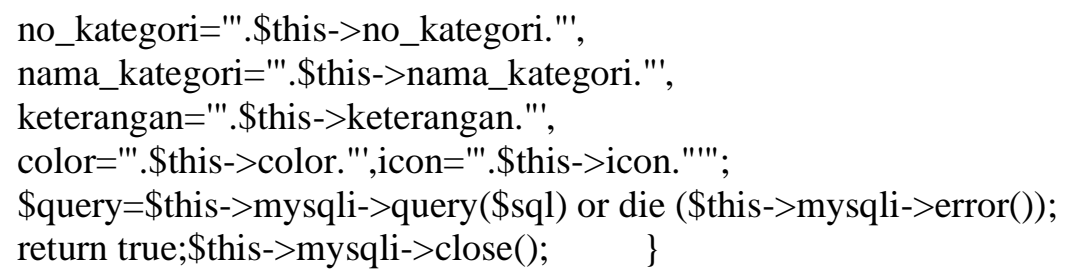

\section{KESIMPULAN}

Berdasarkan hasil analisa dan penelitian yang dilakukan, maka penulis menyimpulkan bahwa proses pelayanan penerimaan tamu, penerimaan surat masuk, mendistribusikan surat keluar, dan legalisir yang saat ini masih dilakukan secara manual, sehingga menyebabkan proses menjadi tidak efektif dan efisien. Hal ini terlihat dari lamanya waktu yang dibutuhkan, mulai dari proses pencatatan data sampai dengan pembuatan laporan, selain itu juga menyebabkan tingkat keakuratan yang rendah, karena masih terdapat beberapa kesalahan. Untuk mengatasi permasalahan diatas, sistem yang diusulkan mampu berjalan secara terkomputerisasi sehingga membuat proses pelayanan menjadi efektif dan efisien, selain itu juga mampu meningkatkan kualitas pelayanan sekolah dengan cepat dan akurat menggunakan beberapa metode analisa dan perancangan yang penulis lakukan.

\section{SARAN}

Dalam penerapan sistem yang berjalan peneliti ingin mengemukakan beberapa saran agar sistem penempatan area kerja bisa menjadi lebih baik lagi diantaranya:

1. Adanya pelatihan yang diberikan kepada pengguna (User) yang akan dijadikan administrator, agar dapat memahami keselurahan penggunaan sistem yang dibuat ini.

2. Apabila sistem ini sudah dapat berjalan maka adanya evaluasi secara berkala penting dilakukan terhadap sistem yang dibuat, untuk perbaikan sistem sesuai dengan keinginan instansi tersebut.

3. Diharapkan dimasa yang akan datang bagi mahasiswa yang mengambil judul skripsi yang sama untuk dapat mengembangkan sistem ini menjadi lebih menarik dan baik

\section{DAFTAR PUSTAKA}

[1] Jenie Sundari. 2016. Sistem Informasi Pelayanan Puskesmas Berbasis Web. IJSEIndonesian Journal on Software Engineering. 2(1). ISSN : 2461-0690.

[2] Junaidi, J., Roji, A., \& Munawar, K. (2015). Konsep Otomatisasi Sistem Pembayaran SPP Online Untuk Mengurangi Tingkat Keterlambatan. Proceedings Konferensi Nasional Sistem dan Informatika (KNS\&I).

[3] Winarno, Satrio., Lisbeth Mananeke., dan Imelda W.J Ogi. 2018. Analisis Pelayanan Konsumen Dan Fasilitas Terhadap Kepuasan Konsumen Kedai Kopi Maxx Coffee Cabang Hotel Aryaduta Manado. Jurnal Emba. 6(3): 1248 - 1257. ISSN 2303-117.

[4] Junaidi, J., Effendy, M. Y., \& Hartono, H. (2015). REKAYASA MODEL APLIKASI SISTEM PRODUCT KNOWLADGE UNTUK MENDUKUNG PENGAMBILAN KEPUTUSAN DALAM MENENTUKAN KINERJA KARYAWAN. CERITA Journal, 1(1), 46-55.

[5] Bpmdp. 2014. Pengertian Pelayanan Terpadu Satu Pintu Kalimantan Tengah dalam http://kalteng.go.id/ogi/viewarticle.asp?ARTICLE_id=1792 diakses pada Sabtu, 10 Maret 2018 pukul 16:00. 
[6] Junaidi, J., Sutrisno, S., \& Janah, K. (2019). MODEL APLIKASI PURCHASING SYSTEM UNTUK MONITORING STOK DALAM MENGURANGI TINGKAT KERUGIAN. SENSI Journal, 5(1), 86-98.

[7] Bpmdp. 2014. Pengertian Pelayanan Terpadu Satu Pintu Kalimantan Tengah dalam http://kalteng.go.id/ogi/viewarticle.asp?ARTICLE_id=1792 diakses pada Sabtu, 10 Maret 2018 pukul 16:00.

[8] Junaidi, J., Setianingsih, R., \& Khotimah, K. (2015). Rancang Bangun Sistem Penerimaan Dan Pengeluaran Barang Menggunakan Java Aplikasi. Proceedings Konferensi Nasional Sistem dan Informatika (KNS\&I)..

[9] Martono, A., \& Junaidi, D. Y. IMULATION GAME BASED ON JARIMAGIC METHOD TO CALCULATE MORE QUICKLY FOR ELEMENTARY STUDENTS.

[10] Junaidi, J., Cholisoh, N., \& Hasanah, N. (2018). Rancang Bangun Sistem Manajemen Aset IT Untuk Pencatatan History Maintenance Sebagai Pendukung Keputusan. SENSI Journal, 4(2), 220-231.

[11] M. Subekti, Warnars Junaidi, H.L.H.S., Y. Heryadi, "The 3 steps of best data warehouse model design with leaning implementation for sales transaction in franchise restaurant", Cybernetics and Computational Intelligence (CyberneticsCom) 2017 IEEE International Conference on, 20-22 Nov 2017.

[12] J. Junaidi, A. Julianto, N. Anwar, S. Safrizal, H.L.H.S. Warnars, K. Hashimoto, "Perfecting a Video Game with Game Metrics", Telkomnika, vol. 16, no. 3, pp. 13241331, June 2018 